\title{
HERITABILITAS, NISBAH POTENSI, DAN HETEROSIS KETAHANAN KEDELAI (Glycine $\max$ [L.] Merrill) TERHADAP SOYBEAN MOSAIC VIRUS
}

\author{
Nyimas Sa'diyah, Hasriadi Mat Akin, Ria Putri, Risa Jamil, \& Maimun Barmawi \\ Jurusan Agroteknologi, Fakultas Pertanian, Universitas Lampung \\ J1. Prof. Soemantri Brodjonegoro No. 1 Bandar Lampung 35145 \\ E-mail: nyimas_diyah@yahoo.com
}

\begin{abstract}
Heritability, potential ratio, and heterosis of soybean (Glycine max [L.] Merrill) resistance to soybean mosaic virus. The use of soybean cultivars with resistance to SMV is a way for controlling soybean mosaic disease. The objective of this research was to estimate the disease severity, the narrow sense heritability, potential ratio and heterosis of resistance character and number of pithy pods, number of healthy seeds, and healthy seeds weight per plant of ten $\mathrm{F}_{1}$ populations of soybean crossing result to SMV infection. The experiment was arranged in a randomized complete block design in two replications. Observed characters were disease severity, number of pithy pods, number of healthy seeds, and healthy seeds weight per plant. The result of this research showed that 1) the crossing combinations those which were resistant to SMV (lower disease severity) were Yellow Bean x Tanggamus, Tanggamus x Orba, and Tanggamus x Taichung, 2) the narrow sense heritability of disease severity was included in medium criteria, 3) number of pithy pods belonged to high criteria, and 4) number of healthy seeds and healthy seeds weight per plant were included in low criteria. The crossing combinations that had low estimation value of heterosis and heterobeltiosis of resistance to SMV infection were Yellow Bean $\mathrm{x}$ Taichung, Bean $\mathrm{x}$ Tanggamus and Tanggamus x B3570. Disease severity or resistance to SMV is influenced by genetic and environmental factors.
\end{abstract}

Key words: heterosis, narrow sense heritability, potential ratio, resistance, soybean, soybean mosaic virus

\begin{abstract}
ABSTRAK
Heritabilitas, nisbah potensi, dan heterosis ketahanan kedelai (Glycine max [L.] Merrill) terhadap soybean mosaic virus. Penggunaan kultivar kedelai yang tahan terhadap serangan SMV merupakan salah satu cara pengendalian penyakit mosaik kedelai. Penelitian ini bertujuan untuk mengetahui keparahan penyakit, besaran nilai duga heritabilitas arti sempit $\left(\mathrm{h}^{2}\right)$, besaran nilai nisbah potensi (hp) dan heterosis karakter ketahanan serta karakter jumlah polong bernas, jumlah biji sehat, dan bobot biji sehat per tanaman sepuluh populasi $\mathrm{F}_{1}$ kedelai hasil persilangan terhadap infeksi SMV. Percobaan ditata dalam rancangan kelompok teracak sempurna dengan dua ulangan. Karakter yang diamati ialah keparahan penyakit (KP), karakter jumlah polong bernas, jumlah biji sehat, dan bobot biji sehat per tanaman. Hasil penelitian menunjukkan kombinasi persilangan yang tahan (tingkat keparahan penyakit rendah) terhadap SMV yaitu Yellow Bean x Tanggamus, Tanggamus x Orba, dan Tanggamus x Taichung, nilai heritabilitas arti sempit karakter keparahan penyakit termasuk ke dalam kriteria sedang, karakter jumlah polong bernas kriteria tinggi, jumlah biji sehat, dan bobot biji sehat per tanaman kriteria rendah. Kombinasi persilangan yang memiliki nilai duga heterosis dan heterobeltiosis rendah untuk ketahanan terhadap infeksi SMV yaitu Yellow Bean x Taichung, Yellow Bean x Tanggamus, dan Tanggamus x B3570. Keparahan penyakit atau ketahanan terhadap SMV dipengaruhi oleh faktor genetik dan lingkungan.
\end{abstract}

Kata kunci: heritabilitas artis empit, heterosis, kedelai, ketahanan, nisbah potensi, soybean mosaic virus

\section{PENDAHULUAN}

Kedelai (Glycine max [L.] Merril) merupakan salah satu komoditas utama setelah padi dan jagung. Komoditas ini memiliki kegunaan yang beragam. Menurut data dari Badan Pusat Statistika 2012, produksi tanaman kedelai terus turun dari 851.286 ton menjadi 783.158 ton. Rendahnya produktivitas kedelai di Indonesia karena petani kurang menguasai teknik budidaya kedelai dan masalah serangan hama dan penyakit tanaman. Berdasarkan hasil survei penyakitpenyakit yang disebabkan oleh virus tanaman kedelai di Indonesia, soybean mosaic virus (SMV) merupakan virus paling penting kedua setelah soybean stunt virus (SSV) (Andayanie, 2009). Penyakit yang disebabkan oleh soybean mosaic virus (SMV) dapat mengakibatkan penurunan hasil kedelai yang tinggi, yaitu 25,48-93,84\% (Andayanie, 2012). 
Penggunaan kultivar kedelai yang tahan terhadap serangan SMV merupakan salah satu cara pengendalian penyakit yang murah, mudah, aman, dan efektif. Penyediaan kultivar yang tahan dapat dikembangkan melalui teknik pemuliaan tanaman. Salah satu teknik pemuliaan tanaman konvensional adalah melalui kegiatan hibridisasi yang bertujuan untuk membentuk keragaman genetik yang selanjutnya akan diseleksi untuk menghasilkan genotipe yang memiliki ketahanan terhadap infeksi SMV.

Seleksi suatu karakter yang diinginkan akan lebih berarti jika karakter tersebut mudah diwariskan. Mudah tidaknya pewarisan suatu karakter dapat diketahui dari besaran nilai heritabilitasnya. Aksi gen suatu sifat tanaman hasil persilangan dapat diketahui dengan melihat nisbah potensinya. Nisbah potensi menunjukkan pengaruh aksi gen hasil persilangan kedua tetua pada keturunannya. Nilai heritabilitas suatu sifat tergantung pada tindak gen (aksi gen) yang mengendalikan sifat tersebut (Jain, 1982). Jika heritabilitas dalam arti sempit suatu sifat bernilai tinggi, maka sifat tersebut dikendalikan oleh aksi gen aditif pada kadar yang tinggi. Sebaliknya, jika nilai heritabilitas dalam arti sempit bernilai rendah, maka sifat tersebut dikendalikan oleh aksi gen non-aditif (dominan atau epistasis) pada porsi yang tinggi (Suprapto \& Kairudin, 2007). Karakter tersebut tidak mudah diwariskan dari tetua kepada keturunannya.

Selain itu, seleksi juga tergantung pada beberapa parameter genetik yang digunakan sebagai pertimbangan agar seleksi efektif yaitu besaran nilai keragaman genetik, heritabilitas, pola segregasi, jumlah gen dan aksi gen serta heterosis (Barmawi, 2007). Heterosis adalah peningkatan karakter $\mathrm{F}_{1}$ dibandingkan dengan karakter terbaik induknya (Welsh, 1991). Pendugaan heterosis dilakukan dengan dua cara yaitu 1) mid parent heterosis (MP), yaitu penampilan hibrida $\left(\mathrm{F}_{1}\right)$ dibandingkan penampilan rata-rata tetuanya dan 2) high parent heterosis (HP)/heterobeltiosis yaitu penampilan hibrida $\left(\mathrm{F}_{1}\right)$ dibandingkan penampilan ratarata tetua terbaiknya (Fehr, 1987).

Berdasarkan kriteria keparahan penyakit, nilai duga heritabilitas arti sempit, nisbah potensi, dan heterosis tersebut maka akan diseleksi hasil persilangan yang akan dilanjutkan untuk generasi selanjutnya. Oleh karena itu, penelitian ini bertujuan untuk mengetahui keparahan penyakit, besaran nilai duga heritabilitas arti sempit, besaran nilai nisbah potensi dan heterosiskarakter ketahanan serta karakter jumlah polong bernas per tanaman, jumlah biji sehat per tanaman, dan bobot biji sehat per tanaman. Sepuluh populasi $\mathrm{F}_{1}$ kedelai hasil persilangan terhadap infeksi SMV.

\section{METODE PENELITIAN}

Tempat dan Waktu. Penelitian ini dilaksanakan di kebun percobaan Fakultas Pertanian, Universitas Lampung dari bulan Februari sampai dengan Juli 2013. Perbanyakan virus dilakukan di lahan depan Laboratorium Benih Fakultas Pertanian Universitas Lampung.

Sumber Inokulum. Sumber inokulum SMV yang digunakan dalam penelitian ini diperoleh dari sepuluh populasi $F_{1}$ hasil persilangan dialel setengah dan lima tetua kedelai (Yellow Bean, Tanggamus, Orba, B 3570, dan Taichung) yang merupakan benih hasil persilangan yang dilakukan oleh Dr. Maimun Barmawi. Benih yang digunakan sebanyak 350 benih. Untuk inokulasi virus digunakan: zeolit, buffer fosfat $\mathrm{pH} 7$, akuades, alkohol $70 \%$, Peubah yang diamati adalah tingkat keparahan penyakit (KP), Jumlah polong bernas per tanaman, jumlah biji sehat per tanaman, dan bobot biji sehat per tanaman

Rancangan Perlakuan. Rancangan perlakuan yang digunakan yaitu rancangan perlakuan tunggal tidak terstruktur yang disusun dalam rancangan kelompok teracak sempurna. Homogenitas ragam dengan uji Bartlett dan kemenambahan model dengan uji Tukey. Setelah data memenuhi asumsi, data dianalisis ragam untuk menduga daya gabung umum dan daya gabung khusus (Tabel 1).

Rumus mencari nilai heritabilitas arti sempit:

dengan:

$$
\mathrm{h}^{2}=\frac{\sigma_{\mathrm{A}}^{2}}{\left(\sigma_{\mathrm{A}}^{2}+\sigma_{\mathrm{D}}^{2}+\sigma_{\mathrm{E}}^{2}\right)}
$$

$\mathrm{h}^{2}=$ hetitabilitas arti sempit

$\sigma_{\mathrm{A}}^{2}=$ varians aditif

$\sigma_{\mathrm{D}}^{2}=2 \sigma_{\mathrm{g}}^{2} ; \sigma_{\mathrm{g}}^{2}=\{1 /(\mathrm{p}+2)\} \times\left(\mathrm{KNT}_{\mathrm{dgu}}-\mathrm{KNT}_{\mathrm{dgk}}\right)$

$\sigma_{\mathrm{D}}^{2}=$ varians dominansi $=\left(\mathrm{KNT}_{\mathrm{dgk}}-\mathrm{KNT}_{\text {galat }}\right)$

$\sigma_{\mathrm{E}}^{2}=$ varians lingkungan $=\mathrm{KNT}_{\text {galat }}$

Rumus mencari nilai nisbah potensi menurut Suprapto \& Kairudin (2007):

dengan:

$$
\mathrm{hp}=\frac{\mathrm{F}-\mathrm{MP}}{\mathrm{HP}-\mathrm{MP}}
$$

$\mathrm{hp}=$ nilai nisbah potensi atau derajat dominansi gen

$\mathrm{F} \quad=$ rata-rata nilai $\mathrm{F}_{1}$

$\mathrm{HP}=$ nilai rata-rata tetua tertinggi

$\mathrm{MP}=$ nilai tengah kedua tetua 
Tabel 1.Sidik ragam untuk rancangan persilangan dialel setengah (metode 2) (Singh \& Chaudhary, 1979)

\begin{tabular}{llll}
\hline \multicolumn{1}{c}{ Sumber keragaman } & \multicolumn{1}{c}{$\begin{array}{c}\text { Derajat } \\
\text { kebebasan }\end{array}$} & $\begin{array}{c}\text { Kuadrat nilai } \\
\text { tengah }\end{array}$ & Kuadrat tengah harapan \\
\hline Kelompok & $\mathrm{r}-1$ & & \\
Persilangan & $1 / 2(\mathrm{p}[\mathrm{p}+1])-1$ & & $\mathrm{\sigma}_{\mathrm{e}}^{2}+\sigma_{\mathrm{D}}^{2}+(\mathrm{p}+2) \sigma_{\mathrm{g}}^{2}$ \\
Daya gabung umum & $\mathrm{p}-1$ & $\mathrm{KNT}_{\mathrm{dgu}}$ & $\sigma_{\mathrm{e}}^{2}+\sigma_{\mathrm{D}}^{2}$ \\
Daya gabung khusus & $\mathrm{p}(\mathrm{p}-1) / 2$ & $\mathrm{KNT}_{\text {dgk }}$ & $\sigma_{\mathrm{e}}^{2}$ \\
Galat & $(\mathrm{r}-1)(1 / 2(\mathrm{p}[\mathrm{p}+1])-1)$ & $\mathrm{KNT}_{\text {galat }}$ & \\
\hline
\end{tabular}

$\mathrm{r}=$ ulangan; $\mathrm{p}=$ jumlah tetua; $\sigma_{\mathrm{e}}^{2}=$ varians lingkungan; $\sigma_{\mathrm{D}}^{2}=$ varians dominansi; dan $\sigma_{\mathrm{g}}^{2}=$ varians genetik.

Gejala heterosis masing-masing variabel yang diamati dihitung menurut Fehr (1987); Rubiyo \& Sudarsono (2011) sebagai berikut :

1) Heterosis rata-rata tetua (mid parent heterosis)

$$
\operatorname{hMP}(\%)=\frac{\mathrm{F}_{1}-\mathrm{MP}}{\mathrm{MP}} \times 100 \%
$$

dengan:

$\mathrm{hMP}=$ heterosis rata-rata tetua (heterosis)

$\mu \mathrm{F}_{1} \quad=$ nilai tengah hibrida

$\mu \mathrm{MP}=$ nilai tengah kedua tetua $=\frac{\mathrm{P}_{1}+\mathrm{P}_{2}}{2}$

2) Heterosis rata-rata tetua tertinggi/Heterobeltiosis (high parent heterosis)

$$
\operatorname{hHP}(\%)=\frac{\mathrm{F}_{1}-\mathrm{HP}}{\mathrm{HP}} \times 100 \%
$$

dengan:

hHP = heterosis rata-rata tetua tertinggi (heterobeltiosis)

$\mu \mathrm{F}_{1} \quad=$ Nilai tengah hibrida

$\mu \mathrm{HP}=$ Nilai tengah tetua tertinggi (high parent)

Inokulasi virus dilakukan 7 sampai 10 hari setelah tanam (daun tripoliat sudah muncul). Tingkat keparahan penyakit diamati pada minggu keempat setelah inokulasi dan dilakukan terhadap sepuluh daun per tanaman serta dihitung dengan rumus (Barmawi, 2007):

$$
\mathrm{KP}=\frac{\sum(\mathrm{n} \times \mathrm{v})}{\mathrm{N} \times \mathrm{Z}} \times 100 \%
$$

dengan:

$$
\begin{array}{ll}
\mathrm{KP} & =\text { Keparahan penyakit }(\%) \\
\mathrm{N} & =\text { Jumlah sampel yang diamati } \\
\mathrm{Z} & =\text { Nilai skor tertinggi } \\
\mathrm{n} & =\text { Jumlah sampel untuk katagori serangan } \\
\mathrm{v} & =\text { Nilai skor untuk katagori serangan }
\end{array}
$$

Gejala penyakit dibagi menjadi 4 skor (Akin, 2006) yang masing-masing artinya:

skor 0 = Tidak bergejala

skor $1=$ Klorosis dan tulang daun memucat

skor 2 = Gejala mosaik dengan klorosis pada tulang daun dan permukaan daun

skor 3 = Gejala mosaik berat dan terjadi pembengkokkan pada permukaan daun, daun melengkung ke bawah atau ke atas

skor 4 = Malformasi daun

\section{HASIL DAN PEMBAHASAN}

Keparahan Penyakit. Varietas Orba dan populasi $\mathrm{F}_{1}$ hasil persilangan Yellow bean x B 3570 memiliki nilai keparahan penyakit (KP) tertinggi berturut-turut $46,22 \%$ dan $32 \%$, sedangkan nilai keparahan penyakit terendah ditampilkan oleh Tanggamus dan populasi $F_{1}$ hasil persilangan Yellow Bean $\mathrm{x}$ Tanggamus dengan nilai KP berturut-turut $25,15 \%$ dan 24,38\%. Berdasarkan kategori ketahanan dapat dilihat Tanggamus termasuk kategori tahan, Yellow Bean, B 3570, dan Taichung agak tahan, sedangkan Orba agak rentan. Populasi $\mathrm{F}_{1}$ hasil persilangan Yellow Bean x Tanggamus, Tanggamus x Orba, dan Tanggamus $\mathrm{x}$ Taichung termasuk ke dalam kategori tahan, sedangkan kombinasi persilangan yang lain termasuk ke dalam kategori agak tahan (Tabel 2).

Varietas Orba termasuk ke dalam kategori agak rentan. Hal ini menunjukkan bahwa varietas Orba merupakan varietas yang cocok untuk pertumbuhan dan perkembangan SMV terutama untuk virus tersebut bereplikasi yang didukung dengan kondisi lingkungan tanaman yang tidak memberikan respon untuk menghambat virus tumbuh dan berkembang. Penyebab mengapa tanaman dapat menimbulkan reaksi rentan adalah karena terjadinya penurunan permeabilitas selaput sel tanaman sehingga fotosintat yang dihasilkan tanaman tidak bisa disalurkan ke bagian-bagian lain tanaman. 
Selain itu, penurunan aktivitas enzim, penurunan kandungan klorofil pada daun, dan perubahan hasil reaksi fiksasi $\mathrm{CO}_{2}$ yang seharusnya menghasilkan karbohidrat, akan tetapi menghasilkan asam organik untuk sintesis protein virus (Akin, 2006).

Tetua Tanggamus dan populasi $\mathrm{F}_{1}$ hasil persilangan Yellow Bean x Tanggamus, Tanggamus x Orba dan Tanggamus $x$ Taichung memiliki nilai tingkat keparahan penyakit terendah, sehingga termasuk ke dalam kategori tahan. Keadaan ini menunjukkan bahwa varietas Tanggamus, populasi $\mathrm{F}_{1}$ hasil persilangan Yellow Bean $\mathrm{x}$ Tanggamus, Tanggamus $\mathrm{x}$ Orba, dan Tanggamus $\mathrm{x}$ Taichung mampu menghambat pertumbuhan dan perkembangan virus yang menginfeksinya. Tanaman dapat dikatakan tahan apabila tanaman hanya mengalami sedikit infeksi atau infeksi yang terbatas. Tanaman yang tahan mampu menghambat replikasi virus dan melokalisasi virus, sehingga virus tidak tersebar ke bagian lain. Mekanisme ketahanan tanaman terhadap virus berupa penghambatan perpindahan virus jarak dekat dan jarak jauh. Perpindahan jarak dekat merupakan perpindahan antar sel yang berdekatan yang terjadi melalui plasmodesmata, sedangkan perpindahan jarak jauh merupakan perpindahan dari satu organ tanaman ke organ yang lain melalui sistem pembuluh (Akin, 2006).

Heritabilitas Arti Sempit. Nilai duga heritabilitas arti sempit untuk karakter keparahan penyakit adalah 0,32 termasuk ke dalam kriteria sedang. Machfud \&
Sulistyowati (2009) menyatakan bahwa heritabilitas arti sempit yang termasuk ke dalam kriteria sedang menunjukkan faktor lingkungan dan faktor genetik memiliki pengaruh yang sama. Berarti karakter ketahanan dikendalikan oleh aksi gen aditif dan nonaditif pada porsi yang hampir sama (Suprapto \& Kairudin, 2007).

Untuk karakter jumlah polong bernas per tanaman memiliki nilai duga $\mathrm{h}^{2}$ sebesar 0,60 yang termasuk ke dalam kriteria tinggi, hal ini menunjukkan faktor genetik lebih berpengaruh dibandingkan faktor lingkungan. Artinya karakter ini mudah diwariskan dari tetua kepada keturunannya. Karakter jumlah biji sehat per tanaman dan bobot biji sehat per tanaman heritabilitas arti sempit berturut-turut adalah 0,20; dan 0 yang termasuk dalam kriteria rendah (Tabel 3). Kondisi ini mengindikasikan bahwa jumlah biji sehat dan bobot biji sehat per tanaman lebih dipengaruhi oleh faktor lingkungan dibandingkan dengan faktor genetiknya. Hal ini mendukung penelitian Barmawi (2007) tentang ketahanan kedelai terhadap cowpea mild mottle virus yang menyatakan nilai duga heritabilitas dalam arti sempit yang rendah berindikasi bahwa varians genetik aditif untuk karakter tersebut adalah rendah, sebaliknya ragam genetik non-aditif tinggi, sehingga karakter tersebut tidak mudah diwariskan dari tetua kepada keturunannya.

Nisbah Potensi. Nilai nisbah potensi (hp) untuk karakter tingkat keparahan penyakit populasi $\mathrm{F}_{1}$ hasil

Tabel 2. Keparahan penyakit lima tetua kedelai dan sepuluh populasi $F_{1}$ yang terinfeksi SMV

\begin{tabular}{lcc}
\hline \multicolumn{1}{c}{ Varietas/persilangan } & Rerata keparahan penyakit $(\%)^{*}$ & Kategori ketahanan* \\
\hline Yellow Bean & 26,82 & Agak tahan \\
Tanggamus & 25,15 & Tahan \\
Orba & 46,22 & Agak rentan \\
B 3570 & 31,25 & Agak tahan \\
Taichung & 31,66 & Agak tahan \\
Yellow Bean x Tanggamus & 24,38 & Tahan \\
Yellow Bean x Orba & 29,22 & Agak tahan \\
Yellow Bean x B 3570 & 32,00 & Agak tahan \\
Yellow Bean x Taichung & 28,13 & Agak tahan \\
Tanggamus x Orba & 25,25 & Tahan \\
Tanggamus x B 3570 & 26,16 & Agak tahan \\
Tanggamus x Taichung & 24,84 & Tahan \\
Orba x B 3570 & 27,75 & Agak tahan \\
Orba x Taichung & 28,53 & Agak tahan \\
B 3570 x Taichung & 28,13 & Agak tahan \\
\hline
\end{tabular}

*Sangat tahan= 1-10\%; Tahan= 11-25\%; Agak tahan= 26-35\%; Agak rentan= 36-50\%; Rentan= 51-75\%; dan Sangat rentan $=75-100 \%$. 
Tabel 3. Heritabilitas arti sempit untuk karakter keparahan penyakit, jumlah polong bernas, jumlah biji sehat, dan bobot biji sehat

\begin{tabular}{lcc}
\hline \multicolumn{1}{c}{ Variabel } & Heritabilitas $\left(\mathrm{h}^{2}\right)$ & Kriteria \\
\hline Keparahanpenyakit & 0,32 & sedang \\
Jumlah Polong Bernas & 0,60 & Tinggi \\
Jumlah Biji Sehat & 0,20 & Rendah \\
Bobot Biji Sehat & 0 & Rendah \\
\hline
\end{tabular}

Kisaran nilai heritabilitas menurut Mendez-Natera et al. (2012) sebagai berikut: Tinggi: $\mathrm{h} \geq 0,5$; Sedang: $0,2<\mathrm{h}$ $<0,5$; Rendah: $\mathrm{h} \geq 0,2$.

persilangan Yellow Bean $\mathrm{x}$ Tanggamus ( $\mathrm{hp}=-1,91)$, Tanggamus x Taichung (hp $=-1,09)$, Orba x B 3570 (hp = -1,47), Orba $\times$ Taichung (hp =-1,43), dan B 3570 $\mathrm{x}$ Taichung (hp = -16,04) (Tabel 4). Hal ini menunjukkan bahwa karakter keparahan penyakit pada populasi $\mathrm{F}_{1}$ persilangan di atas dikendalikan oleh aksi gen yang bersifat over dominan negatif. Keadaan ini mengindikasikan bahwa zuriat hasil persilangan akan menghasilkan tingkat keparahan penyakit yang lebih rendah dibandingkan dengan tetuanya (ketahanannya lebih tinggi). Sebaliknya pada hasil persilangan Yellow Bean x B 3570, memiliki nilai $(\mathrm{hp}=1,34)$ termasuk dalam kriteria over dominan positif. Berarti zuriat yang dihasilkan akan memiliki tingkat keparahan penyakit yang lebih tinggi daripada tetuanya (ketahanannya lebih rendah) (Tabel 4).

Populasi $\mathrm{F}_{1}$ hasil persilangan Yellow Bean x Orba memiliki nilai $(\mathrm{hp}=-0,75)$ dan Yellow Bean $\mathrm{x}$ Taichung (hp $=-0,46)($ Tabel 4). Kondisi ini menunjukkan bahwa karakter keparahan penyakit pada populasi $\mathrm{F}_{1}$ tersebut dikendalikan oleh aksi gen dominan sebagian negatif. Dengan demikian, populasi $\mathrm{F}_{1}$ hasil persilangan Yellow Bean x Orba dan Yellow Bean x Taichung akan menghasilkan keparahan penyakit yang berada diantara kedua tetuanya namun lebih dipengaruhi oleh tetua yang paling tahan. Populasi $\mathrm{F}_{1}$ hasil persilangan Tanggamus x Orba memiliki nilai $(\mathrm{hp}=-0,99)($ Tabel 4). Keadaan ini mengindikasikan bahwa adanya aksi gen dominan lengkap negatif yang mengendalikan karakter keparahan penyakit. Akibatnya, populasi $\mathrm{F}_{1}$ hasil persilangan Yellow Bean x Orba akan menghasilkan ketahanan yang sama dengan tetuanya yang tahan.

Tingkat keparahan penyakit menunjukkan bahwa populasi $\mathrm{F}_{1}$ hasil persilangan Yellow Bean $\mathrm{x}$ Tanggamus, Tanggamus x Orba, dan Tanggamus x Taichung adalah hasil persilangan yang ketahanannya termasuk ke dalam kategori tahan (Tabel 2). Dilihat dari nilai hp untuk karakter keparahan penyakit, ketiga populasi $\mathrm{F}_{1}$ tersebut masing-masing termasuk ke dalam kriteria over dominan negatif, dominan lengkap negatif, dan over dominan negatif. Dengan demikian, zuriat yang karakternya dikendalikan oleh aksi gen over dominan negatif akan menghasilkan ketahanan yang lebih tahan dari pada kedua tetuanya, sedangkan karakter yang dikendalikan oleh aksi gen dominan lengkap negatif akan menghasilkan ketahanan yang sama dengan tetuanya yang tahan.

Populasi $F_{1}$ hasil persilangan Yellow Bean $x$ Tanggamus untuk karakter jumlah polong bernas per tanaman, jumlah biji sehat per tanaman, dan bobot biji sehat per tanaman memiliki nilai $h p>1$, sehingga karakter tersebut dikendalikan oleh aksi gen over dominan positif. Akibat pengaruh aksi gen yang bersifat over dominan positif, maka zuriat hasil persilangan akan menghasilkan jumlah polong bernas, jumlah biji sehat, dan bobot biji sehat per tanaman akan lebih banyak dibandingkan dari kedua tetuanya (Sriwidarti, 2011).

Populasi $\mathrm{F}_{1}$ hasil persilangan Tanggamus $\mathrm{x}$ Orba untuk karakter jumlah biji sehat, dan bobot biji sehat per tanaman memiliki nilai hp< -1 . Keadaan ini menunjukkan bahwa karakter-karakter tersebut dipengaruhi oleh aksi gen over dominan negatif. Berarti zuriat hasil persilangan akan menghasilkan jumlah biji sehat lebih sedikit, dan bobot biji sehat yang lebih ringan daripada kedua tetuanya. Karakter jumlah polong bernas per tanaman memiliki nilai hp > 0 karena karakter tersebut dipengaruhi efek dominan sebagian positif. Dengan demikian, penampilan $\mathrm{F}_{1}$ hasil persilangan untuk karakter tersebut akan berada diantara kedua tetuanya.

Populasi $F_{1}$ hasil persilangan Tanggamus $x$ Taichung memiliki nilai hp > 1 untuk karakter jumlah polong bernas per tanaman. Oleh karena itu, karakter tersebut dikendalikan oleh aksi gen over dominan positif, sehingga zuriat hasil persilangan akan menghasilkan jumlah polong bernas per tanaman yang lebih banyak dari tetuanya. Karakter bobot biji sehat dipengaruhi oleh aksi gen over dominan negatif. Dengan demikian, zuriatnya akan menampilkan bobot yang lebih rendah dari tetuanya. Aksi gen dominan sebagian positif diduga mengendalikan karakter jumlah biji sehat per tanaman. 


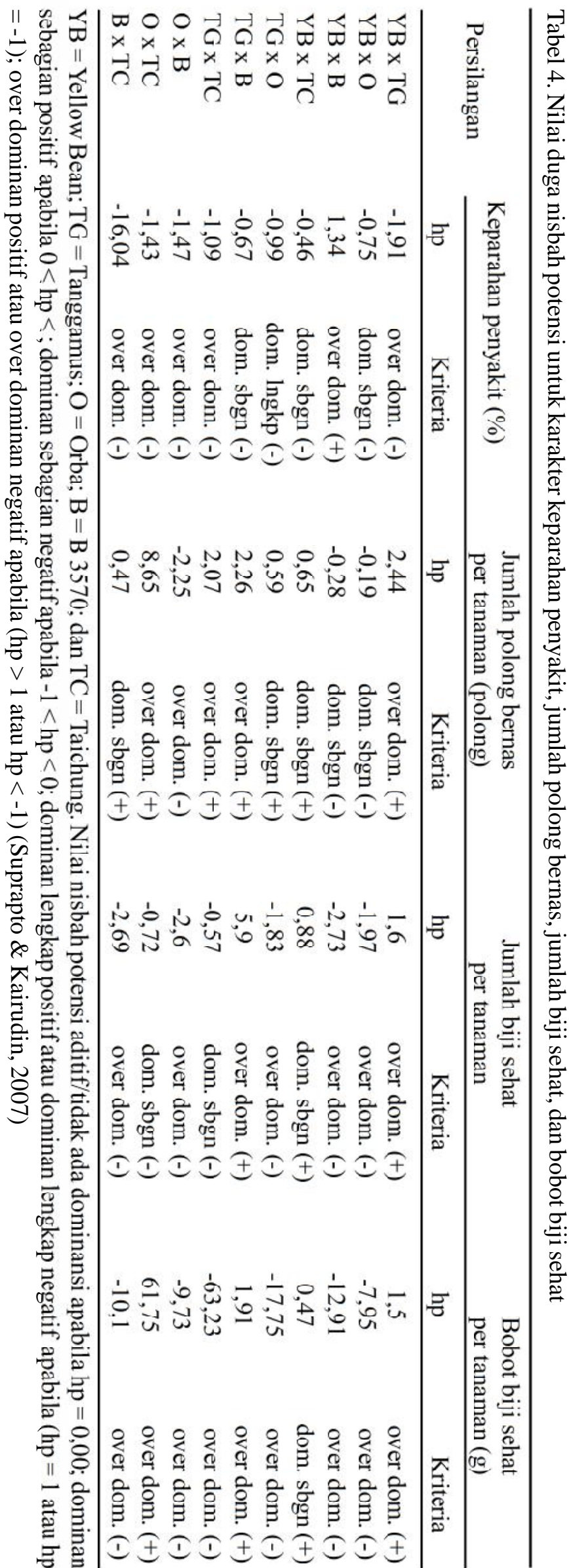

Hal ini mengindikasikan bahwa penampilan zuriat hasil persilangan untuk karakter tersebut akan berada diantara kedua tetuanya.

Heterosis. Hasil penelitian nilai duga heterosis pada karakter keparahan penyakit menunjukkan bahwa populasi $F_{1}$ Tanggamus x Orba (-29,24 dan $\left.-45,37 \%\right)$, Orba x B3570 (-28,36 dan -39,36\%), dan Orba x Taichung (-26,37 dan $-38,27 \%)$ menghasilkan nilai heterosis (rerata tetua) dan heterobeltiosis (rerata tetua terbaik) tertinggi dibandingkan dengan populasi $F_{1}$ kombinasi persilangan lainnya (Tabel 5). Hal ini dapat diartikan bahwa kombinasi persilangan tersebut menghasilkan peningkatan ketahanan untuk keparahan penyakit yang melebihi rerata tetua dan rerata tetua terbaiknya masing-masing berkisar 26,73-29,24\% dan $38,27-45,37 \%$. Penelitian ini sejalan dengan hasil penelitian Rubiyo \& Sudarsono (2011) pada tanaman kakao, yang menyatakan bahwa semakin negatif nilai heterosis maka semakin besar pula pewarisan ketahanan yang dihasilkan dari kombinasi persilangan yang bersangkutan.

Terjadinya mekanisme heterosis menurut Sleper \& Poehiman (2006) dan Fehr (1987), karena adanya akumulasi gen-gen dominan yang unggul dalam suatu genotipe tanaman yang menyebabkan munculnya fenomena heterosis, sedangkan penampilan gen-gen resesifnya akan tertutupi. Dengan demikian, berdasarkan pendapat ini, terjadinya heterosis merupakan aksi dan interaksi gen-gen dominan yang unggul yang terkumpul dalam satu genotipe $\mathrm{F}_{1}$ hasil persilangan kedua tetuanya (Rubiyo \& Sudarsono, 2011).

Pada penelitian ini, jumlah polong bernas, kombinasi persilangan Yellow Bean x Tanggamus, Tanggamus x B3570, Tanggamus x Taichung, dan Orba $x$ Taichung merupakan kombinasi persilangan dengan nilai heterosis dan heterobeltiosis tinggi. Pertambahan jumlah polong bernas yang melebihi rerata tetua dan rerata tetua terbaiknya berkisar $25,54-79,41 \%$ dan 13,65-32,54\% (Tabel 3). Pada karakter jumlah biji sehat, kombinasi persilangan Yellow Bean x Tanggamus dan Tanggamus x B3570 memiliki nilai heterosis dan heterobeltiosis yang tinggi. Pertambahan jumlah biji sehat yang melebihi rerata tetua dan rerata tetua terbaiknya masing-masing berkisar 46,95-88,22\% dan 13,56$63,75 \%$ (Tabel 5). Pada karakter bobot biji sehat kombinasi persilangan yang memiliki nilai heterosis dan heterobeltiosis tinggi yaitu Yellow Bean $\mathrm{x}$ Tanggamus, Tanggamus x B3570, dan Orba x Taichung. Pertambahan bobot biji sehat yang melebihi rerata tetua dan tetua terbaiknya masing-masing berkisar 45,39$169,81 \%$ dan 13,59-169,75\% (Tabel 5). 
Tabel 5. Nilai duga heterosis rata-rata tetua (\%) dan heterosis rata-rata tetua tertinggi (\%) untuk karakter keparahan penyakit, jumlah polong bernas, jumlah biji sehat, dan bobot biji sehat

\begin{tabular}{lrrrrrrrr}
\hline \multirow{2}{*}{ Persilangan } & \multicolumn{2}{c}{$\begin{array}{c}\text { Keparahan } \\
\text { penyakit }\end{array}$} & \multicolumn{2}{c}{$\begin{array}{c}\text { P Polong } \\
\text { bernas }\end{array}$} & \multicolumn{2}{c}{$\sum$ Biji sehat } & \multicolumn{2}{c}{ Bobot biji sehat } \\
\cline { 2 - 9 } & \multicolumn{1}{c}{ hMP } & hHP & hMP & hHP & hMP & hHP & hMP & hHP \\
\hline Y. Bean x Tanggamus & $-6,20$ & $-9,12$ & 25,54 & 13,65 & 46,95 & 13,56 & 43,59 & 13,59 \\
Y. Bean x Orba & $-19,99$ & $-36,78$ & $-8,37$ & $-36,10$ & $-99,96$ & $-99,97$ & $-99,76$ & $-99,81$ \\
Y. Bean x B3570 & 10,21 & 2,40 & $-6,04$ & $-22,90$ & $-41,33$ & $-49,04$ & $-53,33$ & $-55,92$ \\
Y. Bean x Taichung & $-3,81$ & $-11,17$ & 30,52 & $-11,20$ & 43,31 & $-4,12$ & 17,31 & $-7,94$ \\
Tanggamus x Orba & $-29,24$ & $-45,37$ & 20,30 & $-10,60$ & $-45,61$ & $-56,46$ & $-52,16$ & $-52,67$ \\
Tanggamus x B3570 & $-7,23$ & $-16,29$ & 47,77 & 32,32 & 88,22 & 63,75 & 74,96 & 44,74 \\
Tanggamus x Taichung & $-12,57$ & $-21,56$ & 79,41 & 29,67 & $-50,07$ & $-59,57$ & $-58,25$ & $-58,70$ \\
Orba x B3570 & $-28,36$ & $-39,96$ & $-53,48$ & $-62,40$ & $-99,83$ & $-99,88$ & $-99,85$ & $-99,88$ \\
Orba x Taichung & $-26,73$ & $-38,27$ & 38,42 & 32,54 & $-1,10$ & $-2,59$ & 169,81 & 169,75 \\
B3570 x Taichung & $-10,59$ & $-11,17$ & 13,18 & $-11,50$ & $-99,76$ & $-99,83$ & $-99,26$ & $-99,39$ \\
\hline
\end{tabular}

$\mathrm{hMP}=$ heterosis rata-rata tetua, $\mathrm{hHP}=$ heterosis rata-rata tetua tertinggi/heterobeltiosis

Berdasarkan hasil penelitian yang telah dilakukan, ternyata kombinasi persilangan Yellow Bean $\mathrm{x}$ Tanggamus merupakan kombinasi persilangan yang konsisten memiliki peningkatan yang lebih tinggi dari rerata tetua dan rerata tetua terbaiknya untuk karakter ketahanannya lebih tinggi dibandingkan dengan tetuanya (keparahan penyakit yang lebih rendah), jumlah polong bernas, jumlah biji sehat, dan bobot biji sehat per tanaman). Oleh karena itu, kombinasi persilangan Yellow Bean $\mathrm{x}$ Tanggamus dapat dikembangkan untuk memperoleh nomor-nomor harapan yang berpotensi tinggi dan tahan terhadap soybean mosaic virus.

\section{SIMPULAN}

Kombinasi persilangan yang tahan (keparahan penyakit rendah) terhadap SMV yaitu Yellow Bean $\mathrm{x}$ Tanggamus, Tanggamus $x$ Orba, dan Tanggamus $x$ Taichung. Heritabilitas arti sempit untuk karakter keparahan penyakit termasuk ke dalam kriteria sedang, karakter jumlah polong bernas per tanaman kriteria tinggi, jumlah biji sehat per tanaman, dan bobot biji sehat per tanaman termasuk ke dalam kriteria rendah. Kombinasi persilangan yang memiliki nilai duga heterosis dan heterobeltiosis rendah untuk ketahanan terhadap infeksi SMV yaitu Yellow Bean $x$ Taichung, Yellow Bean $x$ Tanggamus, dan Tanggamus x B3570. Keparahan penyakit atau ketahanan terhadap SMV dipengaruhi oleh faktor genetik dan lingkungan.

\section{SANWACANA}

Penulis mengucapkan terima kasih kepada Hibah Strategis Nasional Ditjen Dikti Depdiknas atas bantuan dana yang diberikan pada penelitian ini dan kepada rekanrekan teknisi kebun percobaan Fakultas Pertanian Universitas Lampung atas bantuan yang telah diberikan selama penelitian ini berlangsung.

\section{DAFTAR PUSTAKA}

Akin HM. 2006. Virologi Tumbuhan. Kanisius, Yogyakarta.

Andayanie WR. 2009. Pengelolaan benih bebas Soybean mosaic virus (SMV). J. Agritek. 10(1): 1-11.

Andayanie WR. 2012. Diagnosis penyakit mosaik (Soybean mosaic virus) terbawa benih kedelai. $J$. HPT Tropika 12(2): 185-191.

Badan Pusat Statistik. 2012. Data Produksi Tanaman Kedelai. Katalog BPS 521, Jakarta.

Barmawi M. 2007. Pola segregasi dan heritabilitas sifat ketahanan kedelai terhadap Cowpea mild mottle virus populasi Willis x Mlg 2521. J. HPT Tropika 7(1): 48-52.

Fehr WR. 1987. Heretability. In: Fehr WR (Ed.). Principles of Cultivar Development, Theory and Technique Volume 1. pp. 95-105. Macmillan Publishing Company, New York. 
Jain JP. 1982. Statistical Techniques in Quantitative Genetics. Tata McGraw-Hill Publishing Company Limited, New Delhi.

Machfud M \& Sulistyowati E. 2009. Pendugaan aksi gen dan daya waris ketahanan kapas terhadap Amrasca biguttula. J. Littri. 15(3): 131-138.

Mendez-Natera JR, Rondon A, Hernandes J, \& MerazoPinto JF. 2012. Genetic studies in upland cotton. III. Genetic parameters, correlation and path analysis. Sabrao J. Breed. Genet. 44(1): 112128.

Rubiyo, Trikoekoesoemaningtyas, \& Sudarsono. 2011. Pendugaan daya gabung dan heterosis ketahanan tanaman kakao (Theobroma cacao L.) terhadap penyakit busuk buah (Phytophthora palmivora). J. Littri. 17(3): 124-131.
Singh RK \& Chaudhary BD. 1979. Biometrical Methods in Quantitative Genetic Analysis. India Kalyani Publisher, New Delhi.

Sleper DA \& Poehiman JM. 2006. Breeding Field Crops. Fifth edition. Blackwell, Ames.

Sriwidarti. 2011. Pola pewarisan karakter kualitatif dan kuantitatif kacang panjang (Vigna sinensis var. sesquipedalis $\mathrm{L}$.) keturunan testa coklat $\mathrm{x}$ hitam. Tesis. Universitas Lampung, Bandar Lampung.

Suprapto \& Kairudin NMD. 2007. Variasi genetik, heritabilitas, tindak gen dan kemajuan genetik kedelai (Glycine max Merrill) pada ultisol. J. Ilmu Pertanian Indones. 9(2): 183-190.

Welsh JR. 1991. Dasar-Dasar Genetika dan Pemuliaan Tanaman. Terjemahan Johanes P. Mogea. Erlangga, Jakarta. 